Journal of Contemporary Research in Business, Economics and Finance

ISSN: 2641-0265

Vol. 3, No. 3, pp. 128-143.

2021

Publisher: Learning Gate

DOI: 10.33094/26410265.2021.33.128.143

(C) 2021 by the authors; licensee Learning Gate

\title{
Comparison of Technical and Fundamental Analysis Trading Disciplines on Portfoilo Performance: Short and Long Term Backtest Analysis on Borsa İstanbul National Stock Indices
}

\author{
Mustafa ÖZYEŞíL \\ Istanbul Aydin University, Business Management Dept., Istanbul, Turkey. \\ Email:mozyesil@aydin.edu.tr
}

Received: 16 June 2021; Revised: 19 July 2021; Accepted: 24 August 202 1; Published: 13 September 2021

Abstract: The aim of this study is to comparatively analyze the backtest performances of trading disciplines applied in various portfolio baskets (Bist 30, 50 and 100) for different investment periods (short term - ytd and long term). According to the results of the analysis, it has been determined that in all trading disciplines, the investor has a higher return than the benchmark indicator in a 5-year term, that is, they can earn abnormal returns. Also, the return in the 5-year term is much higher than the 1-year and TTD returns. In the $P / E \& M A$ model, the Bist - 50 index in the 5-year period and the Bist - 100 index in the 1-year period provide the maximum return, while according to the $P / E$ model, the Bist-30 and Bist -50 indices provide optimum returns in all maturity options. Based on these findings, it can be expected that if the trading disciplines used in this study are applied in a long term such as 5 years and on the portfolio basket consisting of Bist-3O and Bist-50 industrial stocks, it will maximize returns. In terms of risk and return, in YTD period, the sharpe and treynor ratios of the model portfolio formed in all trading disciplines except $M / B$ trading discipline were lower than in 1 year in the 5-year investment period. This situation arose due to the increased risk of the portfolio as a result of the extended maturity and is in line with our expectations.

Keywords: Technical analysis, Fundamental analysis, Trading disciplines, $M / B, P / E$, Moving Averages, Backtest, Sharpe, Treynor.

JEL Classification: G10; G11.

\section{Introduction}

One of the most imprtant goal of investors trading in financial markets is to maximize their riskadjusted returns. Therefore, they want to create the optimal portfolio composition for various maturities, instruments and financial market options. The vast majority of investors trading in the market try to consider the both macro and micro risk factors that affect the return of the financial instrument. For instance, the risk of excessive volatility observed in the price movements of the relevant instrument, the risks and associated costs that may arise from the nature of the instrument as a debt / equity security, all other type of risks stemming from the financial, economic and political developments of the country in which the instrument is traded should be taken into account during the investment process. Thanks to the developments in information technologies, advanced financial services and solutions offered by fintech companies, interaction and convergence in capital markets has increased tremendously. For this reason, it is possible that an investor investing in the stock market will be under the influence of a financial or non-financial development anywhere in the world, that is, the investment value will be affected positively or negatively. 
Due to this point reached in financial markets, systematic information management has become much more important. Investors need to create a trading discipline that can be applied systematically, analytically and dynamically, taking into account many macro and micro determining variables such as maturity, structural characteristics of the instrument and the risk profile of the target country. The dynamic expression here refers to the portfolio basket can be revised according to the changing conditions during the investment process.

Two types of analysis are generally used to determine the assets to be taken into the portfolio and disposal during the investment process. First is Fundamental Analysis, which shows which asset should be included in the portfolio and which asset should be sold, and second technical analysis, which provides correct timing for trading activities. In general, fundamental analysis answers the question of which, while technical analysis answers the question of when. The use of these two analyzes in harmony with each other according to various risk and return preferences will increase the chances of success for investors.

In this study, the performance of trading disciplines consisting of various technical and fundamental analysis indicators has been analyzed comparatively in all national stock indexes (Bist-30, Bist-50, Bist 100) of Borsa Istanbul for both the short and long term, through backtest method. The aim is to analyze the performance of the trading disciplines created in different samples and maturity structures comparatively. In the second part of the study, the theoretical framework related to technical and fundamental analysis and various portfolio return performance measures are provided, and in the third part, previous studies conducted in the national and international literature on this subject are discussed. In the fourth chapter, the analysis is performed and findings and results are interpreted.

\section{Establishing a Portfolio}

Financial markets are defined as the physical and digital environment where economic units who have surplus savings and economic units who has a savings deficit with a periodic income less than their expenses come together for fund transfer. Financial markets are classified according to many criteria in the literature. One of these criteria is the maturity. Financial markets are divided as money and capital markets according to their maturity structures. While the markets where the supply and demand for funds with a maturity of 1 year or less come together are called money markets, the markets where the supply and demand for funds with a maturity of more than 1 year come together are called capital markets. Each market has its own characteristics and instruments. There is a close relationship between the development of these markets and the development of the country's general economy growth (Korkmaz, Aydın, \& Sayılgan, 2013). The word portfolio, which means wallet, refers to a basket of financial assets in financial management. In portfolio management, investors trade in money and capital markets, try to earn returns by investing in a portfolio of instruments such as stocks, bonds, treasury bills, gold, foreign exchange and derivative instruments, etc.

\subsection{Analyzes Used in Portfolio Establishing}

Investors perform investment analysis while creating a portfolio. They try to determine the financial assets to be included in the portfolio according to the maturity and risk level they have determined. Since each financial asset has its own unique structural feature, it is crucial to identify financial instruments that meet the needs of investors. Therefore, investors will determine which assets will be included in the portfoilo in line with their risk ve return preferences. During investment evaluation first, the historical return performance of target financial assets is analyzed. In addition, it is tried to estimate the returns that can be obtained if financial assets are included in the portfolio or existing assets are removed from the portfolio. In such estimation studies, the macroeconomic outlook of the country in which the relevant financial asset is traded and the situation of global economies in general should also be examined. Particularly, the financial calendar in the target country and in the world must be thoroughly examined during the investment analysis process. For example, the signal that the US Federal Reserve will give about the monetary policy to be followed in the future will 
directly affect the price of all other local currencies. Not only the foreign exchange market, but also the stock market, which has an reverse correlation with this market, may be affected by such a decision. FED announced that it may change its monetary policy this year by choosing a tapering monetary policy and may increase interest rates or decrease money supply afterwards. As a result of this expected policy change the USD may increase against all other local currencies. Investors who are in short positions especially for USD may need to revise their portfolios according to this recently published announcement. On the other hand, funds coming out of risky instruments like stocks may sail to other alternatives such as foreign exchanges, gold, derivative instruments according to the global financial environment. Then portfolio investments, especially in stock markets of the emerging countries may be decreased.

The efficient market hypothesis assumes that financial markets share information effectively. According to the hypothesis, financial asset prices reflect all the information about the related asset and assume that it reacts to the new information about the financial asset in a timely manner. This hypothesis suggessts that, since the prices of financial assets in a fully efficient market reflect all available information, it is impossible to predict future prices by looking at historical price movements (Uyar, Kelten, \& Moral, 2020). However, it is not easy to talk about a fully efficient market in real life. Simultaneous and fair use of information by all users may not always be in question. In weak and semiefficient market structures where asymmetric information is used, future price predictions of financial assets can be made by using some analysis techniques.

Technical analysis is an analysis method that tries to predict future price movements by using historical price and trading volume information of financial assets. In this analysis technique, the statistical technical indicators obtained from the price and trading volume information of the relevant financial asset and the interpretation of the formations in the charts are used.

Technical analysis pays special attention to the opening, high, closing and low price points when predicting the future price movements of financial instruments. In particular, candlestick charts provide the opportunity for investors to make a more meaningful analysis by showing these pivot price points of the analyzed financial instrument. Because the difference between the opening and closing prices indicates the intraday trend for the relevant instrument, while the difference between the highest and lowest points shows the volatility of the instrument related to the intraday trading range (Fiess \& MacDonald, 2002).

Fundamental analysis tries to determine the real (fair / core) value of a financial instrument by integrating macro and micro analysis regarding on financial instrument. It takes into account both the macroeconomic conditions of the country in where instruments is issued and financial performance of the issuer firm (Esen, 2013). Fundamental analysis uses valuation method, which is carried out by applying Macro Economic Analysis, Sector Analysis and Firm Analysis respectively (Birgili, 2013). The value of the financial instruments which is determined at the end of the valuation process, is the expected fair value of the financial asset according to the analyst. At the investment decision stage, the market value of the financial asset subject to trade is compared with the value determined by the analyst as a result of the valuation. If the market value of the financial asset is higher than the expected fair value, then the relevant financial asset is considered as too expensive or overvalued that means not suitable for purchasing or if it is already included in the portfolio and if it is purchased for the short term trading purposes then immediately it should be excluded profitably from the portfolio.

As stated above, fundamental analysis is generally carried out in 3 stages. In the first stage, the macroeconomic analysis of the country to which the financial asset is issued is performed in an integrated manner with the global economy. Economic indicators such as national and global monetary and fiscal policies, financial calendar, gross national product, CDS premiums, unemployment rate, interest levels, inflation rate, and the expectations of regulators and major market maker banks and funds about these indicarers are analyzed. In summary, at this stage, the global and national risk profile is analyzed. The second stage is the analysis of the sector in which the issuing firm operates. The risks and opportunities of the sector, the current and expected fiscal policies of the sector (for example, tax 
reduction / exemption, etc.), the supply and demand balance of the sector and a possible saturation in the sector are analyzed in general terms. The aim is to invest in dynamic fields that grow rapidly, attract investors and have a healthy supply-demand balance. Third and lastly, the financial performance of the issuing firm is analyzed. For this purpose, the independently audited financial statements of the company (Balance Sheet, Income Statement, Cash Flow Statement, Fund Flow Statement, Change in Shareholder's Equity Statement) and supplementary footnotes are analyzed. Examination of financial statements is carried out by applying some financial analysis techniques. These are analyzes such as Horizontal Analysis, Vertical Analysis, Ratio Analysis and provide the analyst with a general view about the company. The outputs obtained as a result of these analyzes are evaluated together with the assumptions of the company management regarding the operational and financial performance in the future projection. As a result, the fair value of that firm and the financial asset it issues is reached by using some valuation techniques.

Fundamental analysis is much more technical and complex than technical analysis, and generally has meaningful and significant results for medium and long-term investments. For example, in the valuation process, the cash flows expected to be produced by a firm or financial asset in the future are discounted to the present value by using the discount rate. In other words, the present value of the future expected cash flows is calculated. The problem here is the question of what and how the discount rate to be used is determined. The analyst's wrong or misleading perception about the company may cause a very large fluctuate (increase or decrease) in the value of the asset, even if there is a very small change in the discount rate. It may be necessary to accept this situation as a constraint of fundamental analysis. In technical analysis, the future price of a financial asset is estimated rather than its value in the investment decision process. For this reason, it is a suitable to apply technical analysis in all type of maturities, including short, medium and long, as it uses only the transaction price and transaction volume information of the financial asset. Support and resistance points determined in technical analysis and indicators and formations that confirm them are used, so it is possible to trade instantly on the daily line. In technical analysis, even if the price of the financial asset is more than its fair value, if there is still demand for that financial asset, technical indicators will be able to generate buy or hold signals for the relevant financial asset. As a result of all these, technical analysis is a subject that is still being debated in the academic literature.

\subsection{Portfolio Performance Measures}

Portfolio management is a process and the last step of this process is to determine and report the return of the portfolio created. For this purpose, there are many performance measures that are frequently used both in academia and in the sector. Since Sharpe Ratio, Treynor Ratio and Jensen Ratio were used in this study, these criteria will be explained in detail in this part of the study.

\subsubsection{Sharpe Ratio}

The Sharpe ratio was developed by Nobel Prize winner Willam F. Sharpe in 1968. According to this ratio, it is accepted that there is a linear relationship between financial assets that can be shown with a simple regression equation (Uysal \& Adal, 2018). The basic logic in this ratio is to explain with a coefficient how much risk premium the investors earn for the risk they incurr. The higher this coefficient, the more risk-resistant the return of the relevant financial asset is considered. In the calculation of the ratio, the risk premium provided by the financial asset, or in other words the residual return, and the risk of that financial asset are used. The standard deviation of the return of the relevant financial asset is used as the total risk (Bayramoğlu \& Yayalar, 2017).

The Sharpe ratio is calculated by the formula shown in Equation 1 below (Sharpe, 1964):

$$
s=\frac{d^{-}}{\sigma}
$$


The explanation of the notations in the formula is given below:

$\mathbf{S}$ : Sharpe Ratio,

$\mathbf{d}^{-}$: The residual / abnormal return (Risk Premium) provided by the portfolio,

$\boldsymbol{\sigma}:$ Standard Deviation of the Portfolio

The $\mathrm{d}$ - in the equation is the risk premium provided by the portfolio and is calculated as follows in Equation 2:

$$
D^{-}=\mathrm{r}_{\mathrm{p}} \quad \mathrm{r}_{\mathrm{f}} \quad 2 \mathrm{~s}
$$

The explanations of the notations in Equation 2 are given below:

$\mathrm{r}_{\mathrm{p}}=$ return of the portfolio

$r_{\mathrm{f}}=$ risk-free rate

According to many of the studies in the literature and the results encountered in practice, it has been determined that the Sharpe ratio gives more successful results in series with normal distribution. However, it was determined that it was relatively less successful in series with very high kurtosis and skewness values that did not show normal distribution. The Sharpe ratio is a useful ratio when comparing the return performance of the portfolio with benchmark indicator returns such as the general index performance (Samarakoon and Hasan, 2005: 6).

For instance, the information about a stock portfolio is assumed as follows:

1- The average return of the portfolio is $30 \%$,

2- The standard deviation of the portfolio is $40 \%$,

3- The yield of Treasury Bills is 10\%

Based on assumptions above, the Sharpe ratio can be calculated as follows:

Sharpe Ratio of Portfolio $=(\% 30-\% 10) / \% 40=0,5$

According to the result, it can be concluded that the investor gets 0.5 risk premium for each unit standard deviation.

Assuming that the index (benchmark) information of the stock investor in the example is assumed as follows:

1 - The average return of the index is $25 \%$,

2- The standard deviation of the index is $40 \%$,

3- The yield of Treasury Bills is 10\%

According to these assumptions, the Index's Sharpe Ratio is calculated as $=(25 \%-10 \%) / 40 \%=$ 0.375 .

Similar to the explanation made for the portfolio's sharpe ratio, it can be expected that an investor investing in the index will have a risk premium of 0.375 for each unit standard deviation incurred.

As a result, it is observed that the portfolio provides a higher return compared to the index, as the portfolio provides a higher premium against the risk incurred with respect to the index with a 0.5 Sharpe ratio. It can be stated that the investor made a successful portfolio choice as a result of the performance comparison made with the index. The Sharpe ratio allows easy comparison between various portfolios, thanks to its easy applicability.

\subsubsection{Treynor Ratio}

The Treynor ratio is largely similar to the Sharpe ratio but uses the concept of systematic risk instead of the standard deviation used as an indicator of risk in the Sharpe ratio. This ratio calculates the risk premium to be obtained if each systematic risk is incurred (Samarakoon and Hasan, 2005: 6-7). The concept of risk premium in the Sharpe ratio is also used in the Treynor ratio. Treynor ratio is also expressed as Earnings (Return) / Volatility ratio. In summary, this ratio differs from the Sharpe ratio as using the systematic risk of the portfolio as a risk parameter in the calculation. The systematic risk of the portfolio is represented by Beta.

The Treynor ratio is calculated as shown in Equation 3 below (Treynor, 1961): 


$$
T=\frac{r p-r f}{\beta_{p}}
$$

The explanations of the notations in Equation 3 are provided below:

$\mathrm{T}=$ Treynor ratio

$\mathrm{r}_{\mathrm{p}}=$ return of the portfolio

$r_{f}=$ risk-free rate

$\beta_{p}=$ beta of the portfolio

In this ratio, Beta is used as a risk measure, and it expresses the reaction of a financial asset to the change in the return of the benchmark index. Assuming that the Beta value of the portfolio in the given Sharpe ratio example is 1.5 and the Beta value of the benchmark index is 1 , it is obvious that the risk level of the investor's portfolio is higher than the general index. For this reason, it should provide higher returns to the investor than the general index due to the additional risk incurred by the investor's portfolio preference. When we adapt the hypothetical Beta values to the example above, the Treynor ratio will be calculated for portfolio and general index, respectively, as follows:

Treynor Ratio of the Portfolio $=(\% 30-\% 10) / 1,5=0,13$

Sharpe Ratio of the General Index $=(\% 25-\% 10) / 1=0,15$

When we analyze at Treynor ratios, it is observed that the index provides a risk premium of 0.15 for each unit of systematic risk incurred, while the portfolio created by the investor provides a risk premium of 0.13. In summary, the investors should revise their portfoilo composition so that they can earn higher than the index's return.

\subsubsection{Jensen's Alpha Ratio}

This ratio is basically based on the CAPM model and it calculates the alpha value according to the CAPM model. Alpha value reveals return margin comparatively with the expected return of the portfolio.

Jensen's Alpha ratio is calculated by the formula shown in Equation 4 below (Jensen, 1968):

$\alpha$

$$
\begin{aligned}
& \alpha=\text { Jensen's alpha } \\
& r_{p}=\text { return of the portfolio } \\
& r_{m}=\text { return of the market portfolio } \\
& r_{f}=\text { risk-free rate } \\
& \beta_{p}=\text { beta of the portfolio }
\end{aligned}
$$

The alpha in the formula shows how much the average return of the portfolio is higher than the expected return determined by the CAPM model. The alpha value also indicates the ability of the portfolio manager to manage the portfolio. Alpha can take zero, positive and negative values. A negative alpha value indicates that the portfolio is less than the portfoilo's expected return.

\section{Literature Review}

$\mathrm{Ni}$ and Zhang (2005) state that trading strategies have diversified and become more complex over time. In particular, they determined that investors value their investment options by using big data, and in this case, backtest applications for these trading strategies become more difficult and time-consuming. In their study, they introduced the parallel genetic algorithm (PGA), which makes the backtesting of trading strategies more efficient. What is especially emphasized in the study is that the reuse of intermediate results in such backtest applications is very important in reducing the problems. In their analysis, they show that they speed up the backtesting process by using PGAs, and they recommend backtesting within a reasonable timeframe to ensure timely execution of trading strategies. 
Campbell (2005) investigated various backtest applications for the adequacy of value-at-risk (VAR) measurements. In his work, he examined backtest procedures both statistically and from a risk management perspective. In the study, backtests were classified according to whether they examined a var measure for unconditional coverage, independence, or both. In the analysis, backtest models that search a var model on several quantitative criteria instead of a single quantitative criterion are examined. In the simulation experiment created, the statistical estimation power of the backtests was examined. Backtests specified in terms of a loss function were examined and their use in validating var models was analyzed. According to the results of the simulation experiment carried out in the study, it was determined that moderate gains in statistical power can be obtained by examining other quantities as well as the first percentile, compared to the power of a test that examines only the first percentile. According to the results of the analysis, backtests examining several attributes were found to be the most successful in reporting systematic risk, without detecting faulty VAR models.

Emenogu, Adenomon, and Nweze (2020) examined the volatility in daily stock returns of Total Nigeria Plc using 9 types of GARCH models. The GARCH models used in the study are sGARCH, girGARCH, eGARCH, iGARCH, aGARCH, TGARCH, NGARCH, NAGARCH, and AVGARCH, respectively. In the analysis, var estimations and backtests were performed. The data used in the calculation are the daily returns of Total Nigeria Plc stocks for the period 2 January 2001 - 8 May 2017. According to the analysis results, it was found that eGARCH and sGARCH performed better for normal innovations and NGARCH performed better for student innovations. From the results of the estimations, it was determined that the persistence of the GARCH models was stable, except for a few cases where iGARCH and eGARCH were unstable. Based on the VaR analysis and backtesting, the study recommends shareholders and investors to continue their business with Total Nigeria Plc, as possible losses can be overcome with future stock price improvements.

Blomvall and Lindberg (2003) created an investment model based on Stochastic Programming in their work. In the model they have created, they bought at ask price and sold at bid price. They apply the model to the Swedish stock index (OMX), call options in the index, and a situation where risk-free assets can be invested. They solved the 2328 problem in chronological order in order to model the future results of the OMX index. They re-optimized the portfolio every day during the 10-year analysis period. In the analysis, it is also shown that it can create a portfolio that dominates the index in terms of mean and variance, that is, it can obtain higher returns by using options at a certain risk level.

Wong (2010), excessive losses from the use of leverage and financial derivatives require backtesting of value-at-risk based on the size of tail losses. According to the author, the currently used risk measure ignores losses beyond the VAR limit. In his study, he proposed to use the saddle point technique by summing the dimensions of the tail losses. Applied monte carlo simulations show that the technique is extremely powerful and accurate even for small samples. According to the results of the analysis, the backtest method proposed in the study shows that it can detect significant downside tail risks in the S\&P 500.

Bailey, Borwein, and Prado (2017) addressed the overftting problem in their study. Analyzes have been made on a mutual fund and its portfolio consisting mainly of stocks. According to the authors, the main reason why investment strategies that seem perfect on paper fail in practice is the overfitting problem. Existing backtest methods are based on a limited dataset and modeling is built on that, but as new data comes from the market, the model becomes incompatible with them. In the study, they developed a computer software that will design a common portfolio such as the components of the S\&P 500 index and perform backtest analysis for this portfolio. In the backtest analyzes using the software, they showed that the models were insufficient to explain them as new data came to the portfolio. 


\section{Comparative Analysis of Performance of Investment Strategies Consisting of Fundamental and Technical Analysis Trading Disciplines with Backtest Method}

\subsection{Dataset and Sample}

In this part of the study, the performance of some technical and fundamental analysis trading disciplines was measured using the backtest method on Borsa İstanbul national stock indexes. The time dimension of the study was divided into three as 5 years, 1 year, and YTD that covers period from the beginning of the year to the date of analysis. Analyzes were performed separately for each time dimension and the results were shared. As mentioned above, Borsa İstanbul Stock indices Bist - 30, Bist -50 and Bist -100 were selected as the sample for the analysis. In summary, technical and fundamental trading disciplines were analyzed by using 3 different time dimensions on 3 different samples. All analyzes were performed using the Quenstocks program and MS Excel 2016.

\subsection{Methodology}

The trading disciplines analyzed are as follows:

1- Fundamental Analysis Trading Disciplines,

2- Technical Analysis Trading Disciplines,

3- Fundamental - Technical Integrated Trading Disciplines

As a fundamental analysis trading discipline; $\mathrm{P} / \mathrm{E}$ strategy and $\mathrm{M} / \mathrm{B}$ strategy were implemented.

The $\mathrm{P} / \mathrm{E}$ ratio is found by dividing the market value per share by earnings per share. For the investor, the numerator represents the investor's cost, while the denominator represents the investor's earnings. Therefore, a low ratio is considered as more advantageous for the investor since it shows that the relevant stock is cheap.

The $\mathrm{P} / \mathrm{E}$ ratio to be applied as a fundamental analysis trading discipline is shown in Equation 5 below:

The price at which a stock is traded in the market (Unit market price of the

$P / E$ stock)

Net earnings per share

The $\mathrm{M} / \mathrm{B}$ ratio is calculated by dividing the unit market value of a stock by the book value of that stock. Similar to the P/E ratio, the M / B ratio informs the investor whether a stock is cheap or not (overvalued or not). The M / B ratio generally shows that a current market value of a stock is how many times higher than its the book value. Similar to the P / E ratio, low M / B ratio is advantageous for the investor since offering suitable stocks for purchasing.

The $\mathrm{M} / \mathrm{B}$ ratio to be applied as a fundamental analysis trading discipline is shown in Equation 6 below:

M / B $\quad \begin{aligned} & \text { Cuurent Market Price for Per Share (Market Value of a Stock) } \\ & \text { Shareholder's Equity Value Per Share (Book Value of a Stock) }\end{aligned}$

However, in order to make a complete and correct interpretation for both ratios, it is necessary to know the $\mathrm{P} / \mathrm{E}$ and $\mathrm{M} / \mathrm{B}$ ratios of the sector in which the relevant company operates. In this study, since the analysis will be made on the share indices in different sectors, a trading discipline will be created in the form of choosing stocks with low ratios in general.

In calculating the $\mathrm{P} / \mathrm{E}$ and $\mathrm{M} / \mathrm{B}$ ratios, market price of these stocks and financial statements prepared according to IFRS standards, which have been independently audited by the companies announced to the stock exchange, have been used.

As a technical analysis trading discipline, moving averages are used for buy and sell signals. The 5,10, 20 and 50-day moving averages are used to predict the uptrend for the buy signal and the downtrend for the sell signal as follows: 
For a buy signal: the 50-day moving average is expected to be below the 20-day moving average and the 5-day moving average is expected to cross the 20-day moving average upwards. The rule established for the Buy signal is shown in Equation 7 below as follows.

$\operatorname{Mov}(\mathrm{C}, 50)<\operatorname{Mov}(\mathrm{C}, 20)$ and $\operatorname{Crosses} U$ pward $(\operatorname{Mov}(\mathrm{C}, 5), \operatorname{Mov}(\mathrm{C}, 20))$

For the sell signal, the 5 -day moving average is required to cross the 10-day moving average downward. The rule established for the sell signal is shown in Equation 8 below as follows.

CrossesDownward( $\operatorname{Mov}(\mathrm{C}, 5), \operatorname{Mov}(\mathrm{C}, 10)$ ) (8)

As a Integrated technical and fundamental analysis trading discipline, The $\mathrm{P} / \mathrm{E}$ model and the Moving Average model are used together called as P / E \& MA Model. In the analysis, the first 5 stocks that provide the highest return in each of the 3 models applied will be included in the portfolio. In other words, the scope of diversification to be applied in the investment methodology is limited to 5 stocks.

\subsection{Test Results}

4.3.1. Backtest Results Performed for a 5-Year Analysis Period (Long Term)

The backtest results of the P / E \& MA Model carried out in the 5-year period are shown in Table 1 below on the basis of the stock index.

Table-1.

5-Year Analysis Results of the P / E \& MA Model.

\begin{tabular}{|c|c|c|c|c|c|c|c|c|}
\hline Portfoilo & Sharpe & Treynor & $\begin{array}{l}\text { K- } \\
\text { Ratio(Monthly) }\end{array}$ & Jensen & Beta & $\begin{array}{l}\text { Relative Return } \\
\text { According to General } \\
\text { Benchmark Index (\%) } \\
\end{array}$ & $\begin{array}{c}\text { Avg. } \\
\text { Monthly } \\
\text { Return (\%) }\end{array}$ & $\begin{array}{l}\text { Standart } \\
\text { Deviation }\end{array}$ \\
\hline $\begin{array}{l}\text { BIST-100 } \\
\text { (Non } \\
\text { Financials) } \\
\end{array}$ & 2,20 & 6,08 & 0,36 & 4,95 & 0,77 & $1,128,76$ & 0,25 & 2,13 \\
\hline Portfoilo & Sharpe & Treynor & $\begin{array}{l}\text { K- } \\
\text { Ratio(Monthly) }\end{array}$ & Jensen & Beta & $\begin{array}{l}\text { Relative Return } \\
\text { According to General } \\
\text { Benchmark Index }(\%)\end{array}$ & $\begin{array}{c}\text { Avg. } \\
\text { Monthly } \\
\text { Return }(\%)\end{array}$ & $\begin{array}{c}\text { Standart } \\
\text { Deviation }\end{array}$ \\
\hline $\begin{array}{l}\text { BIST-50-(Non } \\
\text { Financials) } \\
\end{array}$ & 2,27 & 6,33 & 0,37 & 5,14 & 0,77 & $1.254,79$ & 0,26 & 2,15 \\
\hline Portfoilo & Sharpe & Treynor & $\begin{array}{l}\text { K- } \\
\text { Ratio(Monthly) }\end{array}$ & Jensen & Beta & $\begin{array}{l}\text { Relative Return } \\
\text { According to General } \\
\text { Benchmark Index }(\%)\end{array}$ & $\begin{array}{c}\text { Avg. } \\
\text { Monthly } \\
\text { Return }(\%)\end{array}$ & $\begin{array}{l}\text { Standart } \\
\text { Deviation }\end{array}$ \\
\hline $\begin{array}{l}\text { BIST-30-(Non } \\
\text { Financials) }\end{array}$ & 2,27 & 6,30 & 0,37 & 5,14 & 0,77 & $1.250,73$ & 0,26 & 2,15 \\
\hline
\end{tabular}

When the application results of the P / E \& MA model, in which technical and fundamental analysis are integrated together, are examined, it is seen that the portfolio, which is constantly updated by trading during the 5-year investment period, provides a return much higher than the return of the Bist100 index, which is considered benchmark in this study. In other words, as a result of the application of this model, it is possible for the investor to earn residual returns (abnormal return). When the results of the model are examined on an index basis, it is observed that the portfolio consisting of Bist-50 industrial shares provides the highest return. Risk-adjusted returns of Bist-50 industrial shares are also higher than other indices. Sharpe and Treynor ratios reached the highest value in the portfolio consisting of Bist-50 industrial shares. The highest risk-resistant returns are provided in this portfolio. As a result, the P / E \& MA model provides much higher returns than the index and should be applied on a portfolio of Bist-50 industrial shares in order to maximize this return.

The backtest results of the M/B Model carried out in the 5-year period are shown in Table 2 below on the basis of the stock index. 
Table-2.

5-Year Analysis Results of M / B Model.

\begin{tabular}{l|c|c|c|c|c|c|c|c}
\hline Portfoilo & Sharpe & Treynor & K-Ratio(Monthly) & Jensen & Beta & $\begin{array}{c}\text { Relative Return } \\
\text { According to General } \\
\text { Benchmark Index (\%) }\end{array}$ & $\begin{array}{c}\text { Avg. } \\
\text { Monthly } \\
\text { Return (\%) }\end{array}$ & $\begin{array}{c}\text { Standart } \\
\text { Deviation }\end{array}$ \\
\hline $\begin{array}{l}\text { BIST-100 } \\
\text { (Non } \\
\text { Financials) }\end{array}$ & 1,13 & 15,13 & 0,40 & 16,10 & 0,99 & 623,70 & 4,33 & 13,23 \\
\hline $\begin{array}{l}\text { Portfoilo } \\
\text { BIST-50- } \\
\begin{array}{l}\text { Fon } \\
\text { Financials) }\end{array}\end{array}$ & Sharpe & Treynor & K-Ratio(Monthly) & Jensen & Beta & $\begin{array}{c}\text { Relative Return } \\
\text { According to General } \\
\text { Benchmark Index (\%) }\end{array}$ & $\begin{array}{c}\text { Avg. Monthly } \\
\text { Return (\%) }\end{array}$ & $\begin{array}{c}\text { Standart } \\
\text { Deviation }\end{array}$ \\
\hline $\begin{array}{l}\text { Portfoilo } \\
\text { BIST-30- }\end{array}$ & Sharpe & Treynor & K-Ratio(Monthly) & Jensen & Beta & $\begin{array}{c}\text { According to General } \\
\text { Benchmark Index (\%) }\end{array}$ & $\begin{array}{c}\text { Monthly } \\
\text { Return (\%) }\end{array}$ & $\begin{array}{c}\text { Standart } \\
\text { Deviation }\end{array}$ \\
\hline $\begin{array}{l}\text { Fon } \\
\text { Financials) }\end{array}$ & 1,00 & 13,42 & 0,38 & 14,37 & 0,99 & 471,65 & 3,83 & 13,30 \\
\hline
\end{tabular}

As a result of applying the $\mathrm{M} / \mathrm{B}$ model during the 5-year analysis period, it is observed that the portfolio return is very high compared to the general benchmark index. Similar to the P / E \& MA model, it is possible for investors to earn residual returns in this model, but it appears to provide lower returns than the P / E \& MA model. In terms of risk-adjusted returns, the Sharpe ratio is found lower than the P / E \& MA model, but the Treynor ratio is much higher. In particular, the reason for the higher Treynor ratio is that portfoilo is not determined by the prices of the stocks, but by the low M / B ratio instead. In the $\mathrm{P} / \mathrm{E} \& \mathrm{MA}$ model, the price of the stock is used in the analysis, which causes the portfolio to be affected by the volatility of the index. In other words, the Beta value of the portfolio increases. Due to the rising Beta value, the Treynor value of the P / E \& MA model is lower than the value of the M / B model. Looking at the results of the model on an index basis, the portfolio consists of Bist-100 non financial stocks provides the highest relative returns compared to the index. Looking at the Sharpe and Treynor ratios, it is observed that this portfolio also has higher risk-adjusted returns than other indices. When we evaluate the results in general, it is possible for investors to obtain residual returns as a result of applying the $\mathrm{M} / \mathrm{B}$ model, and the model should be applied to the portfolio consisting of Bist-100 non financial stocks in order to maximize the return.

The backtest results of the $\mathrm{P} / \mathrm{E}$ Model carried out in the 5-year period are shown in Table 3 below on the basis of the share index.

As a result of the application of the $\mathrm{P} / \mathrm{E}$ model during the 5-year analysis period, it is observed that investors have higher returns than the benchmark index, similar to the other two models. In other words, in this model, it is possible for the portfolio created by trading in a 5-year period to provide residual returns to the investors, but it is seen that this return remains lower than both the $\mathrm{P} / \mathrm{E} \& \mathrm{MA}$ model and the $\mathrm{M} / \mathrm{B}$ model. In terms of risk-adjusted returns, it is seen that the $\mathrm{P} / \mathrm{E}$ model provides higher returns than the P / E \& MA model, but lower than the M / B model. P / E model has a lower Treynor value than the $\mathrm{M} / \mathrm{B}$ model due to the fact that the stock price used in the analysis in the $\mathrm{P} / \mathrm{E}$ model and this increases the Beta value of the portfolio. The fact that the Beta value of the portfolio created according to the $\mathrm{P} / \mathrm{E}$ model is higher than the Beta value of the portfolio created according to the $\mathrm{M} / \mathrm{B}$ model is a proof of this situation. As a result, the portfolio created according to the $\mathrm{P} / \mathrm{E}$ model is more volatile than the portfolio created according to the M / B model. When the results of the model are analyzed on an index basis, it is seen that the portfolio consisting of Bist-30 and Bist-50 non financial stocks provide investors with the highest relative residual return and risk-adjusted returns. 
Table-3.

5-Year Analysis Results of the P / E Model.

\begin{tabular}{|c|c|c|c|c|c|c|c|c|}
\hline Portfoilo & Sharpe & Treynor & $\begin{array}{l}\text { K- } \\
\text { Ratio(Monthly) }\end{array}$ & Jensen & Beta & \begin{tabular}{|lr} 
Relative & Return \\
According & to \\
General Benchmark \\
Index (\%) \\
\end{tabular} & $\begin{array}{l}\text { Avg. } \\
\text { Monthly } \\
\text { Return (\%) }\end{array}$ & $\begin{array}{l}\text { Standart } \\
\text { Deviation }\end{array}$ \\
\hline $\begin{array}{l}\text { BIST-100- } \\
\text { (Non } \\
\text { Financials) } \\
\end{array}$ & 0,89 & 8,92 & 0,18 & 13,92 & 1,39 & 371,58 & 3,58 & 13,93 \\
\hline Portfoilo & Sharpe & Treynor & $\begin{array}{l}\text { K- } \\
\text { Ratio(Monthly) }\end{array}$ & Jensen & Beta & $\begin{array}{l}\text { Relative Return } \\
\text { According to General } \\
\text { Benchmark Index }(\%)\end{array}$ & $\begin{array}{l}\text { Avg. } \\
\text { Monthly } \\
\text { Return (\%) }\end{array}$ & $\begin{array}{l}\text { Standart } \\
\text { Deviation }\end{array}$ \\
\hline $\begin{array}{l}\text { BIST-50- } \\
\text { (Non } \\
\text { Financials) } \\
\end{array}$ & 0,94 & 9,10 & 0,21 & 14,25 & 1,40 & 406,52 & 3,67 & 13,52 \\
\hline Portfoilo & Sharpe & Treynor & $\begin{array}{l}\text { K- } \\
\text { Ratio(Monthly) }\end{array}$ & Jensen & Beta & $\begin{array}{l}\text { Relative Return } \\
\text { According to General } \\
\text { Benchmark Index (\%) }\end{array}$ & $\begin{array}{l}\text { Avg. } \\
\text { Monthly } \\
\text { Return (\%) }\end{array}$ & $\begin{array}{l}\text { Standart } \\
\text { Deviation }\end{array}$ \\
\hline $\begin{array}{l}\text { BIST-30- } \\
\text { (Non } \\
\text { Financials) } \\
\end{array}$ & 0,94 & 9,10 & 0,21 & 14,25 & 1,40 & 406,52 & 3,67 & 13,52 \\
\hline
\end{tabular}

\subsubsection{Backtest Results Performed for the 1-Year Analysis Period (Short Term)}

The backtest results of the P / E \& MA Model carried out in the 1-year period are shown in Table 4. below on the basis of the stock index.

Table-4.

1-Year Analysis Results of the P / E \& MA Model.

\begin{tabular}{|c|c|c|c|c|c|c|c|c|}
\hline Portfoilo & Sharpe & Treynor & $\begin{array}{l}\text { K- } \\
\text { Ratio(Monthly) }\end{array}$ & Jensen & Beta & $\begin{array}{|lr|}\text { Relative } & \text { Return } \\
\text { According } & \text { to } \\
\text { General Benchmark } \\
\text { Index }(\%) & \\
\end{array}$ & $\begin{array}{l}\text { Avg. } \\
\text { Monthly } \\
\text { Return (\%) }\end{array}$ & $\begin{array}{l}\text { Standart } \\
\text { Deviation }\end{array}$ \\
\hline $\begin{array}{l}\text { BIST-100- } \\
\text { (Non } \\
\text { Financials) } \\
\end{array}$ & 3,54 & 11,11 & 0,61 & 9,78 & 0,90 & 235,17 & 0,52 & 2,82 \\
\hline Portfoilo & Sharpe & Treynor & $\begin{array}{l}\text { K- } \\
\text { Ratio(Monthly) }\end{array}$ & Jensen & Beta & $\begin{array}{l}\text { Relative Return } \\
\text { According to General } \\
\text { Benchmark Index }(\%)\end{array}$ & $\begin{array}{l}\text { Avg. } \\
\text { Monthly } \\
\text { Return (\%) }\end{array}$ & $\begin{array}{l}\text { Standart } \\
\text { Deviation }\end{array}$ \\
\hline $\begin{array}{l}\text { BIST-50- } \\
\text { (Non } \\
\text { Financials) } \\
\end{array}$ & 3,88 & 9,24 & 0,44 & 9,01 & 1,00 & 212,97 & 0,48 & 2,38 \\
\hline Portfoilo & Sharpe & Treynor & $\begin{array}{l}\text { K- } \\
\text { Ratio(Monthly) }\end{array}$ & Jensen & Beta & $\begin{array}{l}\text { Relative Return } \\
\text { According to General } \\
\text { Benchmark Index }(\%)\end{array}$ & $\begin{array}{l}\text { Avg. } \\
\text { Monthly } \\
\text { Return }(\%)\end{array}$ & $\begin{array}{l}\text { Standart } \\
\text { Deviation }\end{array}$ \\
\hline $\begin{array}{l}\text { BIST-30- } \\
\text { (Non } \\
\text { Financials) } \\
\end{array}$ & 3,84 & 9,27 & 0,45 & 8,80 & 0,97 & 205,02 & 0,47 & 2,35 \\
\hline
\end{tabular}

As a result of the application of the $\mathrm{P} / \mathrm{E} \& \mathrm{MA}$ model during the 1-year investment period, it is seen that the investors obtain residual returns on the basis of all stock indices. However, when compared with the results of the same model for the 5-year period, the investors had lower residual returns in the 1-year period. Normally, it is accepted that the investment period, that is, the extension of the maturity, increases the risk. When we look at the 1 and 5-year investment period comparisons of the P / E \& MA model, it is seen that the Sharpe ratio is higher in the 1-year period than in the 5-year period. It is possible to explain this situation with decreasing residual returns or increasing standard deviation compared to the 5-year period. In particular, the increase in the standard deviation with the 
increase in maturity, that is, it has a positive correlation, is in line with our antecedent expectations. In summary, due to the longer maturity in the 5-year investment period, the standard deviation of the portfolio is higher, which causes the Sharpe Ratio to be higher. When we evaluate the results of the model on an index basis, the portfolio that gives the optimum result in terms of relative returns and risk-adjusted returns is the portfolio consisting of Bist-100 non financial stocks. When the 1-year results of the P / E \& MA model are evaluated in general, it is possible for the investor to earn residual returns in the 1-year analysis period in this model, but in order to maximize the portfolio return, the model should be applied on the portfolio consisting of Bist-100 non financial stocks.

The backtest results of the M / B Model carried out in the 1-year period are shown in Table 5 below on the basis of the share index.

Table-5.

1-Year Analysis Results of the M / B Model.

\begin{tabular}{|c|c|c|c|c|c|c|c|c|}
\hline Portfoilo & Sharpe & Treynor & $\begin{array}{l}\text { K- } \\
\text { Ratio(Monthly) }\end{array}$ & Jensen & Beta & $\begin{array}{lr}\text { Relative } & \text { Return } \\
\text { According } & \text { to } \\
\text { General Benchmark } \\
\text { Index }(\%)\end{array}$ & $\begin{array}{l}\text { Avg. } \\
\text { Monthly } \\
\text { Return (\%) }\end{array}$ & $\begin{array}{l}\text { Standart } \\
\text { Deviation }\end{array}$ \\
\hline $\begin{array}{l}\text { BIST-100- } \\
\text { (Non } \\
\text { Financials) } \\
\end{array}$ & 0,30 & 2,35 & 0,23 & 1,63 & 1,06 & 4,73 & 0,72 & 8,45 \\
\hline Portfoilo & Sharpe & Treynor & $\begin{array}{l}\text { K- } \\
\text { Ratio(Monthly) }\end{array}$ & Jensen & Beta & $\begin{array}{l}\text { Relative Return } \\
\text { According to General } \\
\text { Benchmark Index }(\%)\end{array}$ & $\begin{array}{l}\text { Avg. } \\
\text { Monthly } \\
\text { Return (\%) }\end{array}$ & $\begin{array}{l}\text { Standart } \\
\text { Deviation }\end{array}$ \\
\hline $\begin{array}{l}\text { BIST-50- } \\
\text { (Non } \\
\text { Financials) } \\
\end{array}$ & $-0,03$ & - $\quad 0,23$ & 0,13 & $-1,14$ & 1,09 & - $\quad 5,69$ & 0,07 & 8,66 \\
\hline Portfoilo & Sharpe & Treynor & $\begin{array}{l}\text { K- } \\
\text { Ratio(Monthly) }\end{array}$ & Jensen & Beta & $\begin{array}{l}\text { Relative Return } \\
\text { According to General } \\
\text { Benchmark Index (\%) }\end{array}$ & $\begin{array}{l}\text { Avg. } \\
\text { Monthly } \\
\text { Return (\%) }\end{array}$ & $\begin{array}{l}\text { Standart } \\
\text { Deviation }\end{array}$ \\
\hline $\begin{array}{l}\text { BIST-30- } \\
\text { (Non } \\
\text { Financials) } \\
\end{array}$ & $-0,03$ & - $\quad 0,23$ & 0,13 & $-1,14$ & 1,09 & - $\quad 5,69$ & 0,07 & 8,66 \\
\hline
\end{tabular}

As a result of the $\mathrm{M} / \mathrm{B}$ model in the 1-year investment period, it is seen that the investor can only get residual returns on the portfolio consisting of Bist-100 non financial stocks, while the relative return is negative in other index types. In other words, if the $\mathrm{M} / \mathrm{B}$ model is applied on a portfolio consisting of Bist-50 and Bist-30 non financial stocks during the 1-year investment period, it will not be possible for investors to earn any residual returns compared to the index. If the 1-year results of the model are compared with the 5-year period results, it has been determined that it can provide much lower returns in all index types. According to the results of the model, it can be concluded that investors should not apply this model in their selected indices for the 1-year investment period. In summary, it is seen that the M / B model failed in all Borsa Istanbul stock indices in a 1-year period.

The backtest results of the $\mathrm{P} / \mathrm{E}$ model carried out in the 1-year period are shown in Table 6 below on the basis of the share index.

Looking at the results of applying the $\mathrm{P} / \mathrm{E}$ model in the 1-year investment period, it is seen that it provides a residual return well above the $\mathrm{M} / \mathrm{B}$ model but below the $\mathrm{P} / \mathrm{E} \& \mathrm{MA}$ model. Due to the nature of the $\mathrm{P} / \mathrm{E}$ ratio, the Beta value of the model is the highest compared to the other two models. In other words, the volatility of the portfolio created by the application of this model is the highest. However, it is seen that it provides high profit in parallel with the increasing risk and the investor can obtain residual return from the portfolio. As a result of the evaluation of the results of the model on an index basis, it is seen that the investor obtains the highest residual and risk-adjusted returns in portfolios consisting of Bist-30 and Bist-50 non financial stocks. 
Table-6.

1-Year Analysis Results of the P/E Model.

\begin{tabular}{|c|c|c|c|c|c|c|c|c|}
\hline Portfoilo & Sharpe & Treynor & $\begin{array}{l}\text { K- } \\
\text { Ratio(Monthly) }\end{array}$ & Jensen & Beta & \begin{tabular}{|lr} 
Relative & Return \\
According & to \\
General Benchmark \\
Index (\%)
\end{tabular} & $\begin{array}{l}\text { Avg. } \\
\text { Monthly } \\
\text { Return (\%) }\end{array}$ & $\begin{array}{l}\text { Standart } \\
\text { Deviation }\end{array}$ \\
\hline $\begin{array}{l}\text { BIST-100- } \\
\text { (Non } \\
\text { Financials) } \\
\end{array}$ & 1,38 & 14,16 & $0,4 \times 1$ & 16,61 & 1,25 & 72,58 & 5,09 & 12,81 \\
\hline Portfoilo & Sharpe & Treynor & $\begin{array}{l}\text { K- } \\
\text { Ratio(Monthly) }\end{array}$ & Jensen & Beta & $\begin{array}{l}\text { Relative Return } \\
\text { According to General } \\
\text { Benchmark Index }(\%)\end{array}$ & $\begin{array}{l}\text { Avg. } \\
\text { Monthly } \\
\text { Return (\%) }\end{array}$ & $\begin{array}{l}\text { Standart } \\
\text { Deviation }\end{array}$ \\
\hline $\begin{array}{l}\text { BIST-50- } \\
\text { (Non } \\
\text { Financials) } \\
\end{array}$ & 1,45 & 13,98 & 0,40 & 17,39 & 1,32 & 77,20 & 5,33 & 12,71 \\
\hline Portfoilo & Sharpe & Treynor & $\begin{array}{l}\text { K- } \\
\text { Ratio(Monthly) }\end{array}$ & Jensen & Beta & $\begin{array}{l}\text { Relative Return } \\
\text { According to General } \\
\text { Benchmark Index }(\%)\end{array}$ & $\begin{array}{l}\text { Avg. } \\
\text { Monthly } \\
\text { Return (\%) }\end{array}$ & $\begin{array}{l}\text { Standart } \\
\text { Deviation }\end{array}$ \\
\hline $\begin{array}{l}\text { BIST-30- } \\
\text { (Non } \\
\text { Financials) }\end{array}$ & 1,45 & 13,98 & 0,40 & 17,39 & 1,32 & 77,20 & 5,33 & 12,71 \\
\hline
\end{tabular}

\subsubsection{Backtest Results Performed for the TTD Analysis Period}

The backtest results of the P / E \& MA Model carried out in the YTD period are shown in Table 7 below on the basis of the stock index.

Table-7.

YTD Analysis Results of the P / E \& MA Model.

\begin{tabular}{|c|c|c|c|c|c|c|c|c|}
\hline Portfoilo & Sharpe & Treynor & $\begin{array}{l}\text { K- } \\
\text { Ratio(Monthly) }\end{array}$ & Jensen & Beta & $\begin{array}{lr}\text { Relative } & \text { Return } \\
\text { According } & \text { to } \\
\text { General Benchmark } \\
\text { Index }(\%)\end{array}$ & $\begin{array}{l}\text { Avg. } \\
\text { Monthly } \\
\text { Return (\%) }\end{array}$ & $\begin{array}{l}\text { Standart } \\
\text { Deviation }\end{array}$ \\
\hline $\begin{array}{l}\text { BIST-100- } \\
\text { (Non } \\
\text { Financials) } \\
\end{array}$ & 0,42 & 0,89 & 0,07 & 3,05 & 0,98 & 21,69 & 0,05 & 2,05 \\
\hline Portfoilo & Sharpe & Treynor & $\begin{array}{l}\text { K- } \\
\text { Ratio(Monthly) }\end{array}$ & Jensen & Beta & $\begin{array}{l}\text { Relative Return } \\
\text { According to General } \\
\text { Benchmark Index }(\%)\end{array}$ & $\begin{array}{l}\text { Avg. } \\
\text { Monthly } \\
\text { Return (\%) }\end{array}$ & $\begin{array}{l}\text { Standart } \\
\text { Deviation }\end{array}$ \\
\hline $\begin{array}{l}\text { BIST-50- } \\
\text { (Non } \\
\text { Financials) } \\
\end{array}$ & 0,76 & 1,58 & 0,15 & 3,87 & 1,01 & 27,70 & 0,08 & 2,11 \\
\hline Portfoilo & Sharpe & Treynor & $\begin{array}{l}\text { K- } \\
\text { Ratio(Monthly) }\end{array}$ & Jensen & Beta & $\begin{array}{l}\text { Relative Return } \\
\text { According to General } \\
\text { Benchmark Index }(\%)\end{array}$ & $\begin{array}{l}\text { Avg. } \\
\text { Monthly } \\
\text { Return (\%) }\end{array}$ & $\begin{array}{l}\text { Standart } \\
\text { Deviation }\end{array}$ \\
\hline $\begin{array}{l}\text { BIST-30- } \\
\text { (Non } \\
\text { Financials) }\end{array}$ & 0,76 & 1,58 & 0,15 & 3,87 & 1,01 & 27,70 & 0,08 & 2,11 \\
\hline
\end{tabular}

As a result of the $\mathrm{P} / \mathrm{E} \& \mathrm{MA}$ model during the YTD period, it is seen that the investor earns more than the index. In other words, it is possible for the investor to earn residual return as a result of applying this model by trading during the YTD period. However, when this model is compared with the results in the 5-year and 1-year periods, it is seen that the YTD period provides the lowest residual return. It is noteworthy that the YTD period, which has almost the same Beta value in the 1-year period, provides only \%33 of the 1-year period's return. In summary, if it is necessary to choose between the 1-year model and the YTD model for an investor who does not plan for a long-term investment, it is obvious that if the investors choose the 1-year model, they will get 3 times higher return at the same 
risk level compared to YTD. Therefore, the application of the P / E \& MA model for a 1-year period will be more attractive to the investor. When the returns on the index basis are analyzed comparatively, it is expected that investors will maximize their returns in case of investing in the portfolio consisting of Bist-30 and Bist-50 non financial stocks in terms of both residual returns and risk-adjusted returns.

The backtest results of the M / B Model carried out in the YTD period are shown in Table 8 below on the basis of the stock index.

Table-8.

YTD Analysis Results of the M / B Model.

\begin{tabular}{|c|c|c|c|c|c|c|c|c|}
\hline Portfoilo & Sharpe & Treynor & $\begin{array}{l}\text { K- } \\
\text { Ratio(Monthly) }\end{array}$ & Jensen & Beta & $\begin{array}{lr}\text { Relative } & \text { Return } \\
\text { According } & \text { to } \\
\text { General Benchmark } \\
\text { Index }(\%)\end{array}$ & $\begin{array}{l}\text { Avg. } \\
\text { Monthly } \\
\text { Return (\%) }\end{array}$ & $\begin{array}{l}\text { Standart } \\
\text { Deviation }\end{array}$ \\
\hline $\begin{array}{l}\text { BIST-100- } \\
\text { (Non } \\
\text { Financials) } \\
\end{array}$ & $-0,75$ & $-\quad 2,78$ & - $\quad 0,08$ & 8,53 & 1,61 & 6,46 & 1,29 & 5,98 \\
\hline Portfoilo & Sharpe & Treynor & $\begin{array}{l}\text { K- } \\
\text { Ratio(Monthly) }\end{array}$ & Jensen & Beta & $\begin{array}{l}\text { Relative Return } \\
\text { According to General } \\
\text { Benchmark Index }(\%)\end{array}$ & $\begin{array}{l}\text { Avg. } \\
\text { Monthly } \\
\text { Return (\%) }\end{array}$ & $\begin{array}{l}\text { Standart } \\
\text { Deviation }\end{array}$ \\
\hline $\begin{array}{l}\text { BIST-50- } \\
\text { (Non } \\
\text { Financials) } \\
\end{array}$ & $-1,57$ & $-\quad 6,45$ & - $\quad 0,03$ & 2,34 & 1,45 & $-\quad 3,60$ & $-\quad 2,69$ & 5,95 \\
\hline Portfoilo & Sharpe & Treynor & $\begin{array}{l}\text { K- } \\
\text { Ratio(Monthly) }\end{array}$ & Jensen & Beta & $\begin{array}{l}\text { Relative Return } \\
\text { According to General } \\
\text { Benchmark Index (\%) }\end{array}$ & $\begin{array}{l}\text { Avg. } \\
\text { Monthly } \\
\text { Return (\%) }\end{array}$ & $\begin{array}{l}\text { Standart } \\
\text { Deviation }\end{array}$ \\
\hline $\begin{array}{l}\text { BIST-30- } \\
\text { (Non } \\
\text { Financials) }\end{array}$ & $-1,57$ & $-\quad 6,45$ & 0,25 & 2,34 & 1,45 & $-\quad 3,60$ & 2,69 & 5,95 \\
\hline
\end{tabular}

Considering the results of applying the M / B model throughout the YTD period, it is expected that investors will earn a residual return only if they invest in the portfolio consisting of Bist-100 non financial stocks, similar to the results of the analysis for the 1-year period. However, it is seen that this return is well below the 5-year period returns. However, it is oberserved that investors can no longer earn returns in other index types. If we evaluate the results of the model in general, it can be accepted that the M / B model is not attractive for the investor for both the 1-year and YTD periods, which are considered short-term in this study, and the portfolio performance is unsuccessful. According to the results, it will be possible for investors who apply the $\mathrm{M}$ / B model to obtain higher relative returns compared to the index in the 5 -year period.

The backtest results of the P / E Model carried out in the YTD period are shown in Table 9 below on the basis of the share index.

It is observed that if the $\mathrm{P} / \mathrm{E}$ model is applied throughout the YTD period, it provides positive residual returns to the investor. However, this return is considerably lower than the returns obtained in the 5-year and 1-year periods. Especially when we compare the YTD and 1-year period in terms of their close maturities, it is seen that if the investor applies the $\mathrm{P} / \mathrm{E}$ model, they will get much more returns in the 1-year period compared to the YTD period, even though they have almost the same Beta values. Therefore, it would be more attractive for the investor to apply the $\mathrm{P} / \mathrm{E}$ model for a 1-year period. In addition, the $\mathrm{P} / \mathrm{E}$ model is much more successful than the $\mathrm{M} / \mathrm{B}$ model for both the 1-year period and the YTD period. When we evaluate the results of the model on an index basis, it is expected that investors will get the highest return in terms of both residual returns and risk-adjusted returns if they invest in a portfolio consisting of Bist-30 and Bist-50 non financial stocks. 
Table-9.

YTD Analysis Results of the P/E Model.

\begin{tabular}{|c|c|c|c|c|c|c|c|c|}
\hline Portfoilo & Sharpe & Treynor & $\begin{array}{l}\text { K- } \\
\text { Ratio(Monthly) }\end{array}$ & Jensen & Beta & $\begin{array}{|lr|}\text { Relative } & \text { Return } \\
\text { According } & \text { to } \\
\text { General Benchmark } \\
\text { Index (\%) }\end{array}$ & $\begin{array}{l}\text { Avg. } \\
\text { Monthly } \\
\text { Return (\%) }\end{array}$ & $\begin{array}{l}\text { Standart } \\
\text { Deviation }\end{array}$ \\
\hline $\begin{array}{l}\text { BIST-100- } \\
\text { (Non } \\
\text { Financials) } \\
\end{array}$ & $-0,04$ & - $\quad 0,56$ & - $\quad 0,13$ & 5,99 & 0,80 & 13,42 & - $\quad 0,13$ & 10,07 \\
\hline Portfoilo & Sharpe & Treynor & $\begin{array}{l}\text { K- } \\
\text { Ratio(Monthly) }\end{array}$ & Jensen & Beta & $\begin{array}{l}\text { Relative Return } \\
\text { According to General } \\
\text { Benchmark Index }(\%)\end{array}$ & $\begin{array}{l}\text { Avg. } \\
\text { Monthly } \\
\text { Return }(\%)\end{array}$ & $\begin{array}{l}\text { Standart } \\
\text { Deviation }\end{array}$ \\
\hline $\begin{array}{l}\text { BIST-50- } \\
\text { (Non } \\
\text { Financials) } \\
\end{array}$ & 0,02 & 0,13 & - $\quad 0,12$ & 17,12 & 2,09 & 13,70 & 0,08 & 11,31 \\
\hline Portfoilo & Sharpe & Treynor & $\begin{array}{l}\text { K- } \\
\text { Ratio(Monthly) }\end{array}$ & Jensen & Beta & \begin{tabular}{|l|} 
Relative Return \\
According to General \\
Benchmark Index (\%)
\end{tabular} & $\begin{array}{l}\text { Avg. } \\
\text { Monthly } \\
\text { Return (\%) } \\
\end{array}$ & $\begin{array}{l}\text { Standart } \\
\text { Deviation }\end{array}$ \\
\hline $\begin{array}{l}\text { BIST-30- } \\
\text { (Non } \\
\text { Financials) } \\
\end{array}$ & 0.02 & 0.13 & -0.12 & 17,12 & 2,09 & 13.70 & 0.08 & 11,31 \\
\hline
\end{tabular}

\section{Conclusion}

As a result of the huge developments in information and communication technologies, the internet revolution and the global developments that accelerate this process, the effects of globalization have begun to be felt at an increasing rate. The economic borders between the countries have been removed and the convergence between the economies of the countries has increased. In particular, as a result of the rapid spread of information within seconds, the interaction between the economies of the countries has reached maximum levels. Today, an economic data announced in the USA can be priced in seconds by the stock markets of other countries. As a result of such rapid dissemination of information, investors (individuals) traded in the market can instantly access information and developments about the financial instrument and issuer institution they want to trade. For this reason, information management in portfolio management is one of the most important issues for today's investment environment, with exceptions such as aistmetic information. One of the most important issues in portfolio management today is to obtain positive risk-adjusted returns. Investors need to use dynamic trading disciplines that they regularly apply and revise as needed, in order to make the most effective decision within the symmetric or asymmetric information bombardment they are exposed to. Technical and Fundamental Analysis methods are at the forefront of the most used methods in portfolio creation in practice. In the simplest terms, fundamental analysis answers the question of which instrument will be included in the portfolio and removed from the portfolio, while technical analysis indicates when this buy-sell transaction (trading activity) will be made. In this study, the performance of the most widely used technical and fundamental analysis trading disciplines in portfolio management will be measured with the backtest method in order to update the existing literature and share new findings on the subject.

For this purpose, analyzes were made on the portfolios of stocks of non-financial (industrial and other) companies traded in Borsa Istanbul's national stock indexes, Bist-30, Bist-50 and Bist-100. In other words, it was studied on 3 different samples used in the study. As the time dimension of the study, 5 years, 1 year and YTD periods were chosen to guide the investors. In this way, analysis was performed for 3 different time dimensions in each of 3 different samples. As a trading discipline in the analysis, P / E Model, M / B model and P / E \& MA model, in which P / E and moving averages, which are indicators of Technical Analysis, are used together. In the P / E and M / B model, the main purpose is to include stocks which fair value is cheap (discount / not overvalued) compared to their market value and price. In the P / E \& MA model, on the other hand, it is to take stocks that are both cheap and have an upward trend, that is, technically giving a buy signal, into the portfolio. According to 
the results of the analysis, it has been determined that the P / E \& MA model provides both maximum positive residual return to the investor and maximum risk-adjusted return in all index and all time dimensions. This finding in the study is significant in that it reveals that fundamental analysis and technical analysis are not substitutes for each other, but rather complementary types of analysis. As a result, the return of the investor will be high if fundamental and technical analysis trading disciplines are used together. Another important finding in the study is the comparison of $\mathrm{P} / \mathrm{E}$ and $\mathrm{M} / \mathrm{B}$ models. While the M / B model provides higher returns to the investor in the 5-year analysis period, the $\mathrm{P} / \mathrm{E}$ model provides higher returns to the investor in the 1-year and YTD periods, which are shorter investment periods. It can even be stated that the M / B model fails in the 1-year and YTD periods. Based on these results, it can be expected that the use of the M / B model in relatively longer-term analyzes will be more advantageous for the investor. If we analyze at the results of the analysis on the basis of the index, portfolios consisting of Bist - 50 in the 5-year period, Bist-100 in the 1-year period and Bist-30 and Bist-50 non financial stocks in the YTD period provide maximum returns in the $\mathrm{P} / \mathrm{E}$ \& MA model. In terms of the $\mathrm{P} / \mathrm{E}$ model, portfolios consisting of Bist-30 and Bist-50 non financial stocks provide maximum returns in all time periods.

\section{References}

Bailey, D., H., Borwein, J., M., \& Prado, M., L. (2017). Stock portfolio design and backtest overfitting. Journal of Investment Management, 15(1), 1-16.

Bayramoğlu, M. F., \& Yayalar, N. (2017). Evaluation of portfolio performance criteria based on total risk in portfolio selection. Bolu Abant İzet Baysal University Journal of Social Sciences Institute, 17(1), 1-28.

Birgili, M. E. (2013). Explanation of investors using technical analysis method with behavioral finance models a research in Turkey. Adnan Menderes University, SBE, Master Thesis.

Blomvall, J., \& Lindberg, P. O. (2003). Back-testing the performance of an actively managed option portfolio at the Swedish stock market, 1990-1999. Journal of Economic Dynamics and Control, 27(6), 1099-1112.Available at: https://doi.org/10.1016/s0165-1889(02)00056-8.

Campbell, S., D. (2005). A review of backtesting and backtesting procedures. Finance and Economics Discussion Series 2005-21, Board of Governors of the Federal Reserve System (U.S.), 2005(21), 1-23.Available at: https://doi.org/10.17016/feds.2005.21.

Emenogu, N. G., Adenomon, M. O., \& Nweze, N. O. (2020). On the volatility of daily stock returns of total Nigeria Plc: Evidence from GARCH models, value-at-risk and backtesting. Financial Innovation, 6(1), 1-25.Available at: https://doi.org/10.1186/s40854-020-00178-1.

Esen, S. (2013). Application of technical analysis method with fuzzy logic approach: Imkb 30 example. Sakarya University, SBE: These.

Fiess, N. M., \& MacDonald, R. (2002). Towards the fundamentals of technical analysis: Analysing the information content of high, low and close prices. Economic Modelling, 19(3), 353-374.Available at: https://doi.org/10.1016/sO2649993(01)00067-0.

Jensen, M. (1968). The performance of mutual funds in the period 1945-1964. The Journal of Finance, 23(2), 389-416.Available at: https://doi.org/10.1111/j.1540-6261.1968.tbo0815.x.

Korkmaz, T., Aydın, N., \& Sayılgan, G. (2013). Portfolio management. Eskisehir: T.C. Anadolu University.

Ni J., Zhang C. (2005) An Efficient Implementation of the Backtesting of Trading Strategies. In: Pan Y., Chen D., Guo M., Cao J., Dongarra J. (eds) Parallel and Distributed Processing and Applications. ISPA 2005. Lecture Notes in Computer Science, vol 3758. Springer, Berlin, Heidelberg. https://doi.org/10.1007/11576235_17

Samarakoon, L., P., Hasan, T. (2005), Portfolio Performance Evaluation, The Encyclopedia of Finance, C. F. Lee, Editor, Springer, 2005, pp. 617-622.

Sharpe, W. F. (1964). Capital asset prices: A theory of market equilibrium under conditions of risk. The Journal of Finance, 19(3), 425-442.Available at: https://doi.org/10.2307/2977928.

Treynor, J.L. (1961). Market Value, Time, and Risk. Finance Educator: Courses.

Uyar, U., Kelten, G. S., \& Moral, T. (2020). Technical analysis for investors: Bitcoin and ethereum applications. Journal of Financial Research and Studies, 12(23), 653-671.

Uysal, M., \& Adall, Z. (2018). Performance measurement of pension mutual funds in Turkey: Performance comparison of Islamic pension mutual funds and traditional pension mutual funds. Fiscaoeconomia, 2(2), 50-73.Available at: https://doi.org/10.25295/fsecon.2018.02.004.

Wong, W., K. (2010). Backtesting value-at-risk based on tail losses. Journal of Empirical Finance, 17(1), 526-538.Available at: https://doi.org/10.1016/j.jempfin.2009.11.004.

Journal of Contemporary Research in Business, Economics and Finance
ISSN: $2641-0265$
Vol. 3, No. 3, pp. $128-143,2021$
DOI: $10.33094 / 26410265.2021 .33 .128 .143$
C) 2021 by the authors; licensee Learning Gate

